\title{
A MEMORIAL TO HERBERT BLOCH (1911-2006)
}

Herbert Bloch, a path-breaking archaeologist and historian, died peacefully at the age of 95 on September 6, 2006. Born in Berlin on August 18, 1911, he enrolled in the University of Berlin after excellent training at the Kaiser-Friedrich-Gymnasium, dedicating himself with equal intensity to Ancient History, Classical Philology, and Classical Archaeology. In his 7 semesters there (1930-33) his most influential teachers were U. Wilcken in history, W. Jaeger and E. Norden in philology, and G. Rodenwaldt in archaeology. In a reminiscence of Rodenwaldt (no. 116; references are to the bibliography of Bloch by J. A. Bodel in JRA 13 [2000] 16163) he noted that he attended all Rodenwaldt's lectures and seminars and that his first published article, though written in Italian, was based on a paper in his seminar. G. M. A. Hanfmann, later Bloch's colleague at Harvard, was a fellow student. Bloch also participated in the Philological Seminar, which required long papers written in Latin. His edition of and commentary on the fragments of the Greek historian Philistos of Syracuse, which he had written for the Seminar, were so well done that Rodenwaldt, apparently encouraged by Jaeger, recommended that the young scholar immediately submit it as a doctoral dissertation.

When Hitler seized power in Germany (January 30,1933), Bloch decided to leave Berlin at once and continue his studies in Rome, where he remained more than 5 years (September 1933January 1939). There he completed his university studies in Roman history, earning the doctoral degree in 1935 and the Diploma di perfezionamento in 1937 with a thesis on the religious policy of Commodus under the direction of A. Momigliano. His interest in archaeology continued, however, and he served on the staff of the Ostia excavations directed by G. Calza as assistant for inscriptions and brick stamps from February 1938 to January 1939. As he watched troubles mount in Germany, he found his usual workplace, the German Archaeological Institute, under its director L. Curtius "an island paradise in the deluge". His scholarship and linguistic skills brought unusual opportunities. The Italian historian G. De Sanctis enjoyed having him visit to translate German articles for him, then discuss them - a marvelous opportunity for a young scholar. He was less pleased when in 1938 he was asked to do a 'rush job', to translate into German the exhibition catalogue for the reconstructed Ara Pacis. Adolf Hitler was paying a State visit and Mussolini wanted to show off the monument of Rome's imperial greatness; no one else could translate the catalogue so quickly and well. Bloch decided to help the country which had taken him in, rather than scorn the one that had driven him out, and produced a flawless translation. Unfortunately, Mussolini's desire to please Hitler led to the promulgation of racial laws soon after and Bloch had to pull up his roots once more. His brother Egon, whom he was unable to bring from Germany, died in Auschwitz; his father died in 1943 shortly before he would have met the same fate.

Bloch left for America early in 1939 with a student visa. He had excellent recommendations from Rodenwaldt and other teachers and was helped by Hanfmann, who had established himself at Harvard University a few years earlier. Bloch became connected with Harvard, then (1941-42) was named to a fellowship at Dumbarton Oaks, the newly-established Harvard center for Byzantine studies in Washington, D.C. While he held his fellowship, he was hired by the Harvard Classics Department. The war years were difficult. As an enemy alien he could not join the American army as he wished, but he taught GIs maths at Harvard during the war. He was able to obtain American citizenship in 1946. America and Harvard gave some stability to his life and he stayed until his retirement, rising from Instructor to become Pope Professor of the Latin Language and Literature (1973-82).

His scholarship regularly utilized different disciplines. His first major work, "I bolli laterizi e la storia edilizia romana" (1936-1938, no. 3) started from a historical investigation of the Villa of Hadrian at Tivoli. He discovered a large number of new brick stamps in the Villa, then extended his work to published stamps and new finds at Ostia and in major imperial complexes in and around Rome. His revolutionary study demonstrated that these stamps provided unappreciated evidence for imperial architectural history. "If the vitality of innovative research can be measured through its afterlife, as a point of reference, and in generating new research, the first of Bloch's many magna opera should be valued at the highest level", according to E. M. Steinby (JRA 13 [2000] 201-6, n.7). This work was republished with comprehen- 
sive indices in 1949 (no. 27), and reprinted in 1968. Bloch's genius was to consider the stamped bricks under multiple aspects: consular dates, iconography, location in the buildings, the brickyards in which they were made, and their owners and managers. In subsequent articles he used brick stamps to clarify the architectural history of other buildings at Ostia, Rome, and nearby. These studies also contributed to that thorough knowledge of the topography of Rome which is apparent in his review article of the publication of the Marble Plan (no. 67) and in other articles and reviews.

Bloch excelled at setting inscriptions in their historical and prosopographical contexts. Two early articles may be cited. In 1944 (no. 16) he used a new inscription from Ostia and a lead pipe first mentioned in 1936 to establish that the Aqua Traiana served not only Trastevere, but the Baths of Trajan and other places throughout the city. In 1945, another inscription from Ostia, recording the rebuilding of the temple of Hercules in A.D. 393-94, invited a full reconsideration (no. 20) of the personal and political motivations of the attempted pagan revival in Rome. The article was developed in a lecture at the Warburg Institute (no. 69; later republished in a German translation, no. 90).

A second major interest was Greek and Latin historiography, continuing the field he had studied in Berlin and Rome. Even as an archaeologist, the historians were on his mind. He used to tell how, while engaged in the excavations at Ostia, the crew who opened up a room found an inkpot in which there were still traces of dry ink. The thought came to him: "to think that Tacitus might have dipped his pen in this ink!" Soon after his arrival in the United States, he contributed a major article on 4th-c. Greek historiography to the volume of studies in honour of W. S. Ferguson (no. 7). His analysis of the issues surrounding the authorship of the Hellenica Oxyrhynchia established his expertise and was quickly followed by another on Herakleides of Lembos' epitome of the Aristotelian collection of polis constitutions (no. 11). ${ }^{2} \mathrm{He}$ wrote acute reviews of several volumes of F. Jacoby's Fragmente der Griechischen Historiker and his study of the historians of Athens (Atthis), as well as other reviews and articles on historiographical subjects. In 1956 he published an exemplary edition of Jacoby's articles on Greek historiography with a full bibliography. Jacoby chose him to continue the work on FGrHist, and for many years he planned to do so but had to pass on the project to younger scholars because of other commitments (chiefly to Monte Cassino). The parts of Jacoby's Nachlass relating to Part IIIC he transferred to C. Fornara, and the rest to a team of scholars led by G. Schepens and J. Bolansée, who continue it. Although he regularly taught courses in the Latin historians at Harvard, he treated them only in a few articles. Those on the structure of Sallust's fragmentary Historiae (no. 66), based on a careful analysis of the Fleury manuscript, and a collaborative article with the eminent palaeographer B. Bischoff on another Sallust fragment in Vienna (no. 100), may be singled out.

The study of the history of the monastery of Monte Cassino, which grew to occupy most of Bloch's later years, began in 1940 from his investigation of the manuscripts of Tacitus. Already in Berlin he had become familiar in the mediaeval seminar of E. Caspar with the monastery and its 12th-c. librarian, Peter the Deacon. While in Rome, Bloch became interested in the activities of Peter the Deacon and abbot Desiderius. In 1941, he published a short paper in English (no. 12) demonstrating the startling fact that Peter the Deacon was familiar with Tacitus' Agricola. At Dumbarton Oaks he wrote a monograph, Monte Cassino, Byzantium and the West in the earlier Middle Ages (no. 22). Completed in 1942 but only published in 1946, it marks the beginning of his lifetime devotion to the monastery and its history.

In the interval, the allied bombardment of Monte Cassino (February 1944) had shocked Bloch, for whom it represented the continuity of the western civilized tradition, the enduring symbol of the passing on of culture from one generation to the next. One can imagine the effect of this news on a man who had already twice had to abandon his home and his adopted country with their great cultural centers of Berlin and Rome. Almost 30 years later, after the monastery

1 The full title and correct date are The conflict between paganism and Christianity in the fourth century (1963).

2 The correct date is 1940. 
had been completely rebuilt, he published a controversial article (no. 92) examining the factors behind the decision to bomb and the futility of the destruction. Although he understood the pressing needs of the allied armies, he concluded that "the bombardment ... remains and will remain forever a disgrace to our time and our civilization". His introduction to his later Monte Cassino book speaks warmly of his love for the Benedictine tradition and the monks.

Already in 1941 Bloch had realized that a history of Atina, a town near the monastery, written in the 17 th $\mathrm{c}$. and containing valuable source material, must still be preserved in manuscript. If he could have seen it in 1941, he would have found it intact. When he finally was able to travel to Atina in 1951, he discovered that the manuscript had been badly damaged during the war. Nevertheless, he was able to establish warm relations with the owner and persuade him to give the manuscript volumes to the Vatican library, where they could be properly restored and preserved. He worked on an edition of this material in his free time for many years before entrusting it to his student Carmela Franklin, who published the edition in 1996 (cf. no. 117).

At the same time he continued other projects related to Monte Cassino, producing a monograph in 1953 (no. 42) on the forgeries by which Peter the Deacon was able to win the French monastery of Glanfeuil as a dependency of the abbey. When in 1959 G. De Luca suggested that he republish his two Monte Cassino essays, he determined to add new material revealed by the destruction of 1944 . Not only had the bombs laid bare some traces of the earlier basilica built by Desiderius (including the mosaic floor), but the damaged great bronze doors of the abbey revealed a long-held secret: some of the panels of the bomb-shattered doors, inscribed with a long list of all the possessions of the abbey, were found to have been re-used panels from bronze doors ordered by abbot Desiderius from Constantinople in 1066. Beautiful engraved figures of apostles and patriarchs were found on the hidden inner side of some of the panels, concealed ever since the doors had been rebuilt. With his customary thoroughness Bloch set himself to describe the original doors, a most important legacy of the abbey's ties to Constantinople, and to publish and explicate the list of possessions on the panels, a task which was essential to establishing their date (c.1124) and to understanding the abbey's rôle in its most powerful and influential period. In the three-volume work which finally saw the light, Monte Cassino in the Middle Ages (no. 107), he put together a panoramic picture of the abbey and its activity. He made use of every kind of evidence (documents, manuscripts, manuscript illuminations, inscriptions, mosaics, reliefs, architecture, minor arts) and considered not only the abbey's relations with Constantinople, but those with Henry II of Germany (identifying the book presented by that emperor to the monastery, the beautiful illuminations of which strongly influenced later Cassinese practice), the architecture of Desiderius' great basilica, the influential rôle of the Saracen convert and physician Constantinus Alfanus, other comparable bronze doors in Italy, and the monastic dependencies of Monte Cassino throughout Italy. Accompanied by his wife Ellen, who also took photographs of the sites for the book, he succeeded in locating, visiting, and describing the current state of many of these dependencies. As one reviewer concluded, "Every scholar will be mining this monumental book for him/herself for generations to come".

Other major works on Monte Cassino include a monograph (no. 106) which established that Peter the Deacon was the author of the Graphia aureae urbis Romae, an important source for ancient and mediaeval Rome, and another, a thorough account and edition of Peter's fictions concerning the church of Atina (no. 119), published in 1998 when Bloch was 87.

Bloch was a member of the Deutsches Archäologisches Institut and the Pontificia Accademia Romana di Archeologia and was President of the American Philological Association (1968-69). He was President of the Fellows of the Medieval Academy (1990-93) and a member of the Zentraldirektion of the Monumenta Germaniae Historica. He served as Professor-inCharge of the School of Classical Studies (1957-59) and Resident at the American Academy in Rome (1987). He was elected to the American Academy of Arts and Sciences, the American Philosophical Society, and the Finnish Academy of Science and Letters. For his book Monte Cassino in the Middle Ages he was awarded the Praemium Urbis in Rome (1987) and the Haskins Medal of the Medieval Academy (1988). In 1989 he received a laurea 'honoris causa' 
from the Università degli Studi di Cassino and in 1999 the Premio "Cultori di Roma".

Bloch's scholarship was built on meticulous attention to detail and a broad and synthetic vision of issues and problems. The great care he took with the indices to his books, especially those for the brick stamps and the great Monte Cassino volume (he ruefully acknowledged that these had taken him three years), reflected his concern that his research be useful to other scholars. He especially admired scholars who, as he said of R. Meiggs, "combined in equal measure the methods of ancient history, epigraphy, and archeology" (no. 118, p.3). Bloch frequently presented himself as one trained in archaeology, ancient history, and philology, and seemed somewhat bemused that he had become also a mediaevalist, although he credited his training in classical studies for the contributions he could make to mediaeval studies. In his work he regularly combined methodologies: epigraphy, history, and archaeology in the study of brick stamps; philology and history in working with the fragments of lost historians; epigraphy, history, art history, and literary and documentary studies in his work on Monte Cassino. In speaking of this book, and of his work as a mediaevalist, he always stressed a multidisciplinary approach and decried what he called "the blinder syndrome" (see especially no. 115 , written for the studies in honor of F. E. Brown). He had a great respect for earlier scholars, but could correct firmly those who were inaccurate or used poor method. His friendships with fellow scholars young and old on both sides of the Atlantic were warm and enduring.

Bloch honoured his teachers at Berlin and Rome, and himself was an outstanding teacher. He entertained students at his home in Belmont (MA), whose idiosyncrasies he enjoyed pointing out: the elaborate mansard slate roof and iron lightning rod reflected the style used by the same architectural firm that designed Memorial Hall at about the same time. We students remember the warm environment created by his second wife Ellen, who combined excellent cooking with Southern hospitality. Bloch worked chiefly in his study at home, but often met his students in his office in the stacks of Widener Library, his 'second home' for so many years. When the present writer rashly noted that the professor was late for an appointment there, he looked in amazement at the shelves loaded with books and asked, "Could you find nothing to occupy yourself here?" J. H. D'Arms, another former student, wrote in 2000 that his "high scholarly standards and courtly manners remain an inspiration to this day". His teaching in Latin historians and mediaeval Latin led to dissertations across a broad spectrum, from Ctesias and Plutarch to Frontinus and Latin satire, as well as many mediaeval subjects. We students recall his insistence on accuracy and method, on the use of every kind of evidence, and on the lasting significance of the humanities.

As is evident from his scholarship, Bloch had a lively curiosity, which led him to investigate anything that aroused his attention. Prompted as a child by the gift from his father of a mineralogy set, he had become an ardent mineralogist, and would embark on family outings to special collections or locales where unusual minerals could be observed. He delighted in nature, and loved bird-watching and walks in the woods. He was a close watcher of the political scene, from international affairs to Boston city government. His admiration for peacemakers and cultivators of culture led him to dedicate his volumes on Monte Cassino to Pope John XXIII and to Giuseppe De Luca, a supporter of scholars. Like P. O. Kristeller at Columbia University, he was very disturbed by the student takeover of University Hall in 1969, stating in a speech in a faculty meeting that such violent behaviour by a gang of young people reminded him of the Nazi youth gangs in Hitler's Germany. He was quite proud of this speech, in which he also lamented the exaggerated violence of the Cambridge police.

Throughout his life, Bloch exemplified a graciousness and humanity seldom seen. His own experience as an exile reinforced his loyalty toward those who had accepted him, to Italy, to the United States, and to Harvard. In the Abbey of Monte Cassino, with its long heritage of nourishing culture, its tradition of learning and study, and its experience of suffering, especially after the destruction of 1944 , he found a spiritual home. ${ }^{3}$

stadter@unc.edu

Philip A. Stadter

3 I am grateful for the help of Nini Bloch, Francis Newton, Paul Meyvaert, Carmela Franklin, Nicola

Terrenato, and Jan Ziolkowski. 